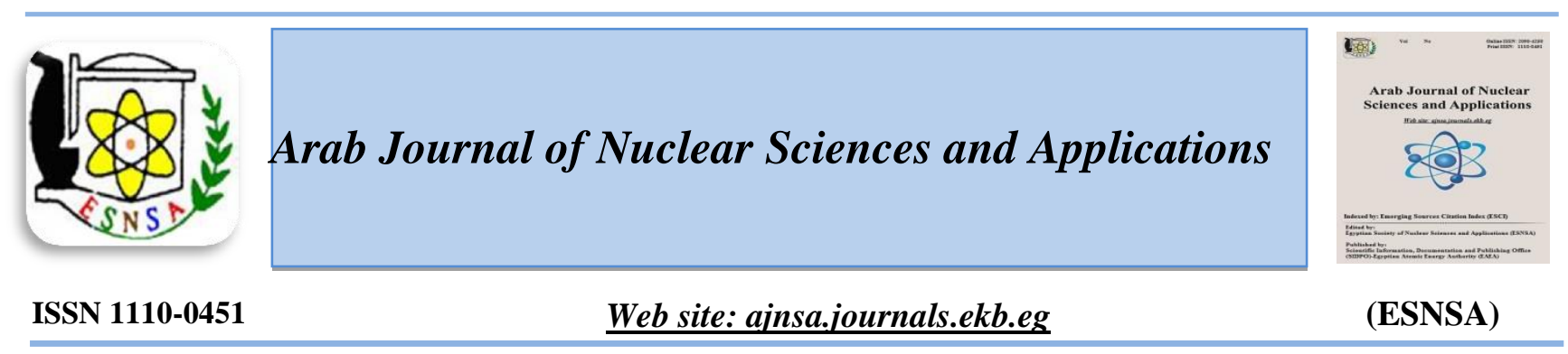

\title{
Physical and Spectral Studies of Mg-Zn Ferrite Prepared Using Different Methods
}

\author{
A.M.A. Henaish \\ Physics Department, Faculty of Science, Tanta University, Tanta, Egypt
}

\begin{abstract}
Received 25 $5^{\text {th }}$ Mar. 2019 Nano particle of Magnesium Zinc ferrite $\left(\mathrm{Mg}_{1-\mathrm{x}} \mathrm{Zn}_{\mathrm{x}} \mathrm{Fe}_{2} \mathrm{O}_{4}\right.$, where $\mathrm{x}=0,0.1,0.2,0.3,0.4$ and 0.5$)$ have Accepted $25^{\text {th }}$ Sep. 2019 been prepared using the standard ceramic technique and mechanical ball milling method. $X$-ray diffraction (XRD), (IR) spectra, and scanning electron microscope (SEM) examinations were carried out to characterize the prepared samples. Single phase cubic spinel structure with a ma $\mathbf{n}$ peak (311) at $2 \theta=$ $34^{\circ}$ was observed for all studied samples. The crystallite size was found to be within the range $37-65 \mathrm{~nm}$. From IR spectra, the absorption bands at $605 \mathrm{~cm}^{-1}\left(v_{1}\right)$ and $435 \mathrm{~cm}^{-1}\left(v_{2}\right)$ were observed and are assigned to tetrahedral (A site) and octahedral (B site) groups complex respectively. The morphological study which was performed using scanning electron microscopy (SEM) shows agglomerated grains with different shapes and sizes. The initial permeability was measured at different frequencies. The fast decrease in initial permeability $\mu \mathrm{i}$ at $\mathrm{Tc}$ is a good reason to be a very strong candidate for magnetic switch devices.
\end{abstract}

Keywords: $M g-Z n$ ferrite, Ceramic, Ball milling, XRD, IR, SEM, Permeability

\section{Introduction}

Nano-ferrites have a wide range of applications due to their novel features including structural, magnetic, electrical and optical properties $[1,2]$. Among many various types of ferrite materials cubic spinel structure especially $\mathrm{Mg}-\mathrm{Zn}$ ferrites, are very promising magnetic materials, which can be used in microwave devices, fuel cells, sensors, heterogeneous catalysis and biomedicine [3, 4]. Recently nano-ferrites showed some advantages in the magnetic properties such as, superparamagnetic which qualified their use in many modern technologies including magnetic fluids, magnetic refrigeration, drug and gene delivery [5-7].

Solid state reaction techniques, such as usual ceramic method and high-energy ball milling, were used to prepare ferrite materials but have limited ability to produce nanoscale particles [8]. In these techniques the raw material usually metals oxides, are well mixed and then calcined at high temperatures [9]. The physical properties of ferrite materials affected by the grain size, microstructure, preparation method and strongly influenced by the cation distribution of ions among the crystallographic sites of the spinel structure [1012].

The mixed spinel ferrite $\mathrm{Mg}_{1-\mathrm{x}} \mathrm{Zn}_{\mathrm{x}} \mathrm{Fe}_{2} \mathrm{O}_{4}$ is expected to have a high magnetic moment and low canting angle at B-site [13].

The aim of the present study is to focus on the synthesis of $\mathrm{Mg}-\mathrm{Zn}$ ferrite by two solid state reaction techniques and study the effect of the preparation method on the physical and structural properties of the studied samples.

Corresponding author: ahmed.henaish@ science.tanta.edu.eg

DOI: $10.21608 /$ ajnsa.2019.11102.1195

(C) Scientific Information, Documentation and Publishing Office (SIDPO)-EAEA 


\section{Experimental Details}

Nano ferrite samples in the chemical formula $\mathrm{Mg}_{1-}$ ${ }_{x} \mathrm{Zn}_{\mathrm{x}} \mathrm{Fe}_{2} \mathrm{O}_{4}(\mathrm{x}=0.0,0.1,0.2,0.3,0.4$ and 0.5$)$ were synthesized using the standard ceramic technique and mechanical ball milling method. The initial raw metal oxides have been collected in stoichiometric ratios. First, all the initial raw metal oxides were well mixed in an agate mortar for 6 hrs and then well mixed in a magnetic stiller using distilled water. All the mixed samples for all prepared ratios were dried in an oven at $100^{\circ} \mathrm{C}$ overnight. In the case of standard ceramic technique, the raw materials were ground very well for $7 \mathrm{hrs}$ using agate mortar. Also, Nanocrystalline $\mathrm{Mg}_{1-\mathrm{x}} \mathrm{Zn}_{\mathrm{x}} \mathrm{Fe}_{2} \mathrm{O}_{4}$ powders were obtained by mechanical ball milling. This method is not only suitable for preparation of nano-ferrite but also suited for the preparation of material with significant properties. The mechanical ball milling was performed in a horizontal oscillatory mill. The mixture ratio of steel balls and the powders was around 15:1 by weight. The powder was milled for around $90 \mathrm{hrs}$. After that all the samples from both methods were preseintered at $800 \mathrm{~K}$ for $4 \mathrm{hrs}$ and left to be cooled gradually to room temperature. All samples were ground again then pressed at room temperature into tablets and toroides for electrical and magnetic studies under pressure 5 Tonn $/ \mathrm{cm}^{2}$. The sample diameter was $1.5 \mathrm{~cm}$ for tablets and for toroides samples the external diameter $3 \mathrm{~cm}$ and internal diameter $2 \mathrm{~cm}$. Then all samples were calcinided at $1100^{\circ} \mathrm{C}$ for $4 \mathrm{hrs}$.

The prepared samples were characterized by $\mathrm{X}$-ray diffraction model Philips model (PW-1729) diffractometer with $\mathrm{Cu}-\mathrm{K} \alpha$ radiation source $\left(\lambda=1.541178^{\circ} \mathrm{A}\right)$. Infrared (IR) spectra were carried out at room temperature using IR spectroscopy model (Perkin Elmer 1430). The grain size was determined from scanning electron microscope analysis (SEM) model (JSM-6360). ESR spectra were recorded for all samples using (JES-FE2XG Joel). The samples in the powder form were placed at the maximum magnetic field in the cavity of the ESR spectrometer. The magnetic properties were measured at room temperature using (VSM) operating system model (v 1.6 control software Oxford OX8JTL England).

\section{Results and Discussion}

\section{$X$-ray diffraction analysis}

The X-ray diffraction patterns of the prepared $\mathrm{Mg}_{1}$. ${ }_{\mathrm{x}} \mathrm{Zn}_{\mathrm{x}} \mathrm{Fe}_{2} \mathrm{O}_{4}(\mathrm{x}=0.0,0.1,0.2,0.3,0.4$ and 0.5$)$ are shown in Figure (1-a) for the sample which was prepared by standard ceramic technique and Figure (1-b) for mechanical ball milling method. The XRD patterns of all $\mathrm{Mg}-\mathrm{Zn}$ ferrite samples after sintering at $1100^{\circ} \mathrm{C}$ indicate a single-phase cubic spinel structure with the main peak at (311). It was observed that the lattice parameters increase with increasing the zinc content $(\mathrm{x})$ as shown in Table (1). This increase may be attributed to the larger $\mathrm{Zn}^{2+}$ ionic radius than that of $\mathrm{Mg}^{2+}$ ionic radius. The increasing in the lattice parameters with $\mathrm{Zn}$ content obeys Vegard's law [14]. Moreover, the crystallite sizes of the prepared samples were calculated using Scherer's formula [15], considering only the factor of full width at half maximum which is the predominant factor.

$$
t=\frac{0.9 \lambda}{h_{\frac{1}{2}} \cos \theta}
$$

Where,

$\lambda$ is the wavelength of $\mathrm{Cu}-\mathrm{K} \alpha(\lambda=1.540598 \AA)$, $h_{\frac{1}{2}}$ is the full width at half maximum (FWHM) in radian, and $\Theta$ is the diffraction angle.

The X-Ray diffraction patterns of the annealed samples at $1100^{\circ} \mathrm{C}$ for $4 \mathrm{hrs}$ milled for $90 \mathrm{hrs}$ indicate the absence of any peaks related to the raw oxides materials. The mechanisms of the formation the single-phase $\mathrm{Mg}-\mathrm{Zn}$ ferrite in ball milling includes two stages [16]:

$$
\begin{aligned}
\mathrm{Mgo}+\mathrm{Fe}_{2} \mathrm{O}_{3} & \longrightarrow \mathrm{MgFe}_{2} \mathrm{O}_{4} \\
\mathrm{MgFe}_{2} \mathrm{O}_{4}+\mathrm{ZnO}+\mathrm{Fe}_{2} \mathrm{O}_{3} & \longrightarrow \mathrm{Mg}_{1-\mathrm{x}} \mathrm{Zn}_{\mathrm{x}} \mathrm{Fe}_{2} \mathrm{O}_{4}
\end{aligned}
$$

The XRD patterns show that the intensity of the diffraction peaks increases by increasing $\mathrm{Zn}$ content indicating that $\mathrm{Zn}$ ions acts as a catalyst for enhancing the solid-state reaction.

The two patterns of materials prepared by ceramic and mechanical ball milling methods are nearly similar expect the branding of same diffraction peaks for samples prepared by mechanical ball milling method which leads to the formation of fine nano-particle at the range from $(65-35 \mathrm{~nm})$. 


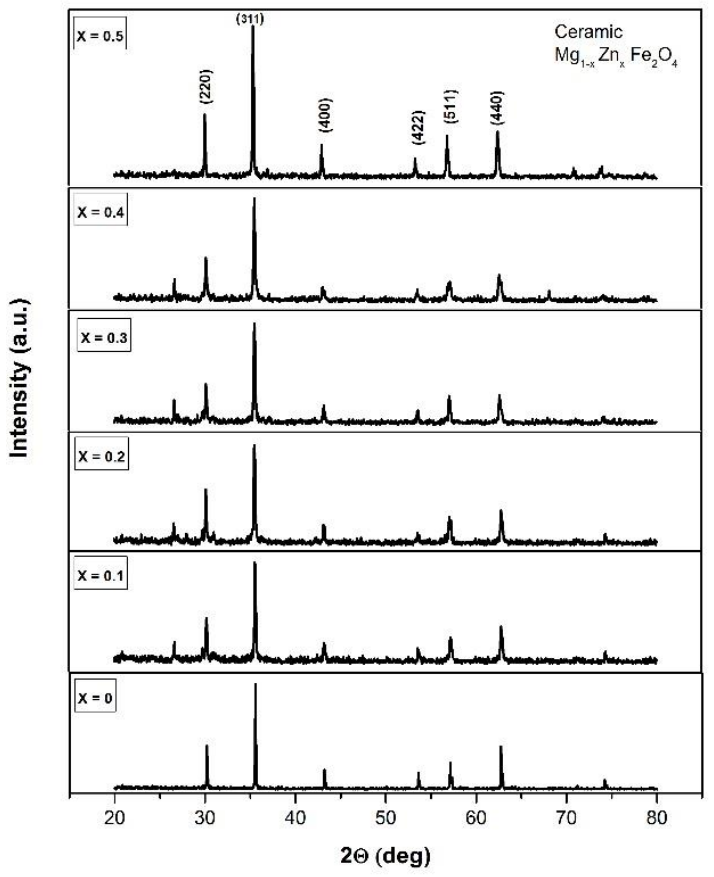

(a)

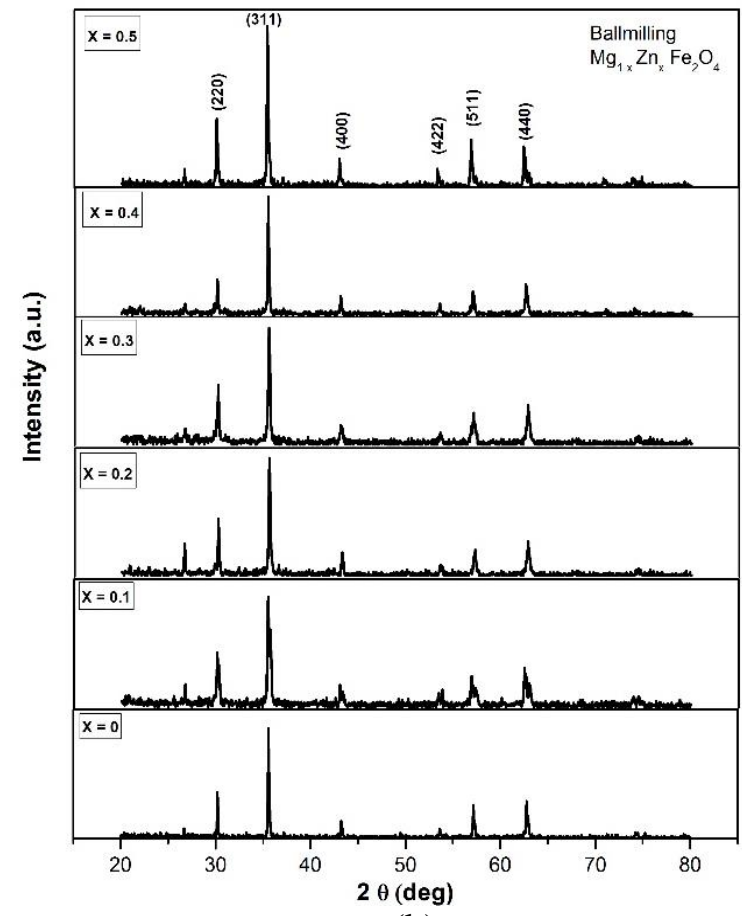

(b)

Figure (1): (a) XRD for $\mathrm{Mg}_{1-\mathrm{x}} \mathrm{Zn}_{\mathrm{x}} \mathrm{Fe}_{2} \mathrm{O}_{4}$ prepared by standard ceramic technique.

(b) XRD for $\mathrm{Mg}_{1-\mathrm{x}} \mathrm{Zn}_{\mathrm{x}} \mathrm{Fe}_{2} \mathrm{O}_{4}$ prepared by mechanical ball milling method

Table (1): The lattice constant and particle size determined from X-ray and grain size from SEM

\begin{tabular}{lllllll}
\hline $\mathbf{X ~ c o n t e n t}$ & $\begin{array}{l}\text { Lattice } \\
\text { constant }(\mathbf{a})\end{array}$ & $\mathbf{D}(\mathbf{n m})$ & $\begin{array}{l}\text { Grain size } \\
(\boldsymbol{\mu m})\end{array}$ & $\begin{array}{l}\text { Lattice } \\
\text { constant } \\
(\mathbf{a})\end{array}$ & $\mathbf{D}(\mathbf{n m})$ & $\begin{array}{l}\text { Grain size } \\
(\boldsymbol{\mu m})\end{array}$ \\
\hline $\mathbf{X = \mathbf { 0 . 1 }}$ & ceramic & & & Ball milling \\
$\mathbf{X = \mathbf { 0 . 2 }}$ & 8.254 & 44.122 & 0.986 & 8.332 & 43.11723 & 0.748 \\
$\mathbf{X = \mathbf { 0 . 3 }}$ & 8.407 & 50.999 & 0.523 & 8.329 & 40.85474 & 0.756 \\
$\mathbf{X = 0 . 4}$ & 8.422 & 40.290 & 1.12 & 8.324 & 37.76604 & 0.713 \\
$\mathbf{X = 0 . 5}$ & 8.482 & 35.435 & 1.08 & 8.297 & 53.11727 & 1.51 \\
\hline
\end{tabular}

The calculated lattice constant as a function of $\mathrm{Zn}$ content was estimated for both samples and reveals that the lattice constant for the ball milling sample is lower than that one prepared by ceramic method as shown in Figure (2). The formation of spinel phase in different stages makes the lattice parameters to be varied and has not one trend.

\section{FTIR spectroscopic analysis}

The I.R spectra at room-temperature of the studies samples $\mathrm{Mg}_{1-\mathrm{x}} \mathrm{Zn}_{\mathrm{x}} \mathrm{Fe}_{2} \mathrm{O}_{4}$ are shown in Figure ( $3 \mathrm{a}$, b). The spectra are recorded from $200-1600 \mathrm{~cm}^{-1}$. The absorption bands around $\left(1100-1400 \mathrm{~cm}^{-1}\right)$ can be attributed to the hydrocarbon impurities in the raw

powder materials, whereas the bond at $\left(850 \mathrm{~cm}^{-1}\right)$ belonging to the stretching vibrations of $(\mathrm{Zn}-\mathrm{O})$ bond.

It is shown from IR spectra that the intensities of the absorption band $\left(v_{1}\right)$ and $\left(v_{2}\right)$ increases by increasing $\mathrm{Zn}$ content, indicating the enhancement of the crystallinity of the samples by increasing $\mathrm{Zn}$ content.

The absence of any peaks in the XRD patterns between $2 \Theta=(30-35$ degree $)$ confirm the 
complete solubility of $\mathrm{Zn}$ ion in the spinel lattice, and the formation of $\mathrm{ZnO}$ absorption band in the

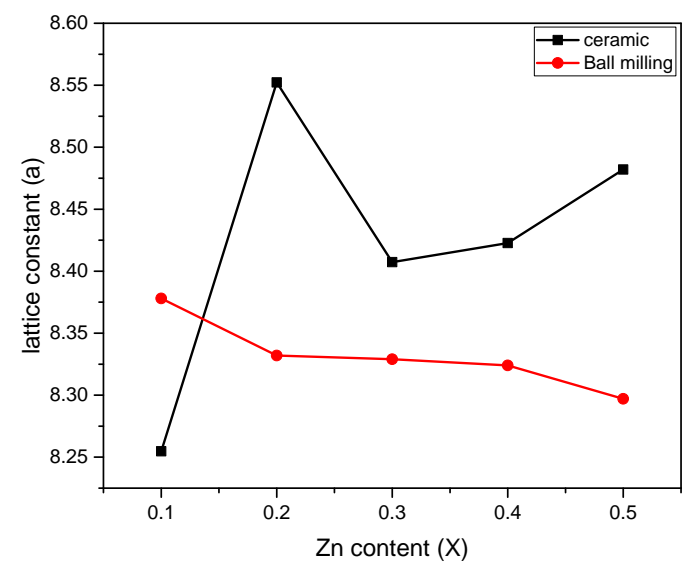

Figure (2): Lattice constant for $\mathrm{Mg}_{1-\mathrm{x}} \mathrm{Zn}_{\mathrm{x}} \mathrm{Fe}_{2} \mathrm{O}_{4}$ as a function of $\mathrm{Zn}$ content

IR spectra does not mean the presence of $\mathrm{ZnO}$ separated from the lattice but this bond formed inti tetrahedral site.

The calculated values of force constant in unit dyne/cm are given in Table (2) for both tetrahedral and octahedral sites. The force constant is given by the equation [17]:

$$
\mathcal{F}=4 \pi^{2} c^{2} v^{2} \mu
$$

Where $\mathrm{c}$ is the velocity of light, $v$ is the frequency and $\mu$ is the reduced mass of $\mathrm{Fe}^{3+}$ and $\mathrm{O}^{-2}$ ions.

The force constant values are related to the bond lengths for the $\left(\mathrm{Fe}^{3+}-\mathrm{O}^{2-}\right)$ bond length at both tetrahedral and octahedral sites.

\section{The magnetic permeability}

The initial permeability of the studied samples $\mathrm{Mg}_{1-\mathrm{x}} \mathrm{Zn}_{\mathrm{x}} \mathrm{Fe}_{2} \mathrm{O}_{4}$ where, ( $\mathrm{x}=0.0,0.1,0.2,0.3,0.4$ and 0.5 ) as a function of temperature from $300 \mathrm{~K}$ to $800 \mathrm{~K}$, was measured at different frequencies $(100$ $\mathrm{Hz}, 1 \mathrm{KHz}$ and $10 \mathrm{KHZ}$ ) for the samples prepared by ball milling and the samples prepared by usual ceramic method are shown in Figs. (4 a, b).

It was found that the initial permeability for both samples increase with increasing the $\mathrm{Zn}$ content and frequency. The permeability increases at low temperature and reaches a maximum at Curie temperature $\left(T_{c}\right)$ and from Hopkinson peak the permeability falls sharply and reaches very low value near zero due to the transition from ferrimagnetic to paramagnetic.

The Curie temperature can be obtained from the $\mu \mathrm{i}$ - T curve by extrapolation of the linear part to the temperature axis. The obtained value of the Curie temperature has the same value obtained from the conductivity measurements as shown in Table (3). The behavior of magnetic permeability can be explained according to Globus model. In this model $\mu \mathrm{i}$ is given by the relation $[18,19]$ :

$$
\mu_{i}=\frac{M_{s}^{2} D}{k}
$$

Where Ms is saturation magnetization, D is the particle size and $\mathrm{k}$ is the magnetic anisotropy.

It is observed that the permeability of usual ceramic method is higher than the ball milling method for $\mathrm{x}=0.5$ and this phenomenon explains the effect of the preparation method on the magnetic behavior of the material [20]. The increase of the magnetic permeability of ceramic samples may be due to the influence of magnetic crystalline anisotropy which has a lower value in ceramic samples.

The doping of $\mathrm{Zn}$ ions by $\mathrm{Mg}$ ions at tetrahedral site displace same ferric ion to octahedral site leading to the decrease of A-B exchange interaction which, decrease the $T_{c}$ curie temperature for both systems by increasing $\mathrm{Zn}$ ions [21].

From the (SEM) morphology studies, it was found that the grain size increases with increasing $\mathrm{Zn}$ ion content which enhances the grain boundaries which are considered the origin of the permeability in the materials [22]. Thus, the initial permeability increases with increasing the $\mathrm{Zn}$ content.

The slope of linear part of initial permeability versus temperature was calculated and is given in Table (3) the high value of the slope illustrated the ability of this material to be used as magnetic switch and magnetic temperature transducers (MTT) devises where the material can transfer the thermal energy to magnetic energy [23]. The sensitivity and performance of the devices using such as (MTT) are direct function of this sudden change. Its value is given by the slope of permeability versus temperature around Curie temperature. 


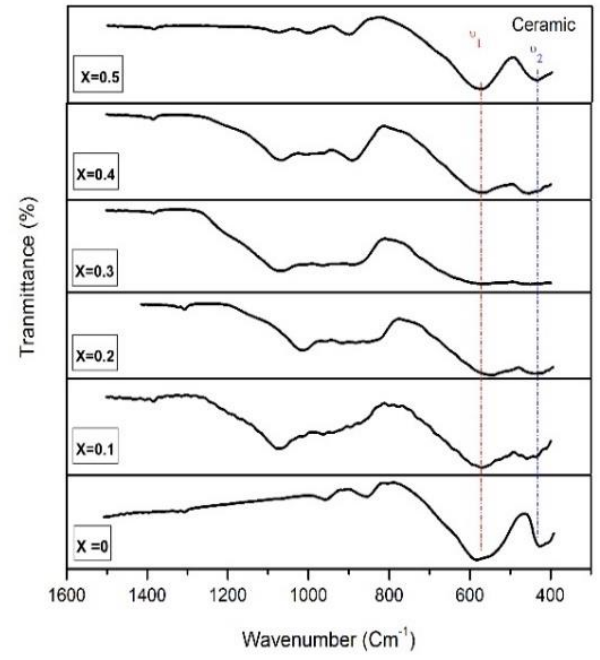

Figure (3-a): FTIR for $\mathrm{Mg}_{1-\mathrm{x}} \mathrm{Zn}_{\mathrm{x}} \mathrm{Fe}_{2} \mathrm{O}_{4}$ prepared by standard ceramic technique

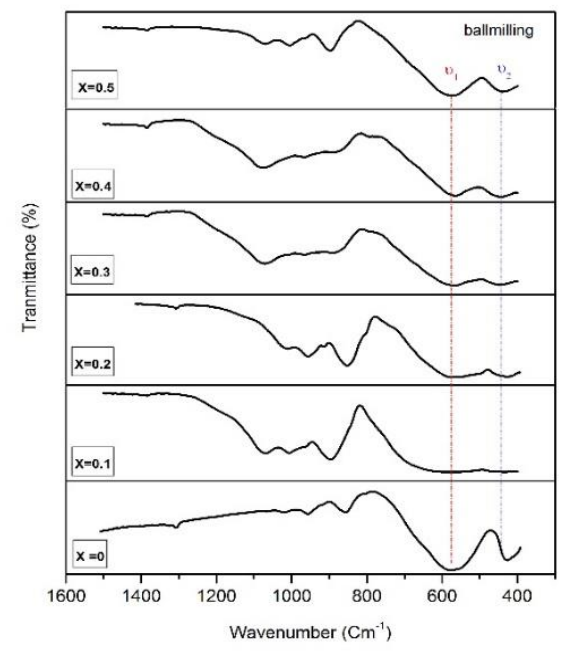

Figure (3-b): FTIR for $\mathrm{Mg}_{1-\mathrm{x}} \mathrm{Zn}_{\mathrm{x}} \mathrm{Fe}_{2} \mathrm{O}_{4}$ prepared by mechanical ball milling method

Table (2): The absorption bands $\left(v_{n}\right)$ and the force constant $(F)$ for both tetrahedral and octahedral sites

\begin{tabular}{|c|c|c|c|c|c|c|c|c|}
\hline $\begin{array}{l}X \\
\text { content }\end{array}$ & $v_{1}\left(\mathrm{~cm}^{-1}\right)$ & $v_{2}\left(\mathrm{~cm}^{-1}\right)$ & $\begin{array}{l}\mathcal{F} \text { tet } \\
(\text { dyne/ cm })\end{array}$ & $\begin{array}{c}\mathcal{F O c t a} \\
(\text { dyne/ cm }\end{array}$ & $\begin{array}{l}v_{1}\left(\mathrm{~cm}^{-}\right. \\
\left.1^{\prime}\right)\end{array}$ & $v_{2}\left(\mathrm{~cm}^{-1}\right)$ & $\begin{array}{l}\mathcal{F} \text { tet } \\
(\text { dyne/ cm) }\end{array}$ & $\begin{array}{l}\text { FOcta } \\
\text { (dyne/ cm }\end{array}$ \\
\hline & \multicolumn{4}{|l|}{ ceramic } & \multicolumn{4}{|c|}{ Ball milling } \\
\hline $\mathrm{X}=\mathbf{0 . 1}$ & 588 & 470 & $2.53 * 10^{5}$ & $1.62 * 10^{5}$ & 559 & 426 & $2.29 * 10^{5}$ & $1.33 * 10^{5}$ \\
\hline $\mathrm{X}=\mathbf{0 . 2}$ & 593 & 472 & $2.58 * 10^{5}$ & $1.63^{*} 10^{5}$ & 565 & 423 & $2.34 * 10^{5}$ & $1.33 * 10^{5}$ \\
\hline $\mathrm{X}=\mathbf{0 . 3}$ & 576 & 472 & $2.43 * 10^{5}$ & $1.63 * 10^{5}$ & 555 & 420 & $2.26 * 10^{5}$ & $1.29 * 10^{5}$ \\
\hline$X=0.4$ & 582 & 474 & $2.48^{*} 10^{5}$ & $1.64 * 10^{5}$ & 557 & 431 & $2.27 * 10^{5}$ & $1.36 * 10^{5}$ \\
\hline$X=0.5$ & 590 & 451 & $2.55^{*} 10^{5}$ & $1.49 * 10^{5}$ & 559 & 441 & $2.29 * 10^{5}$ & $1.33 * 10^{5}$ \\
\hline
\end{tabular}



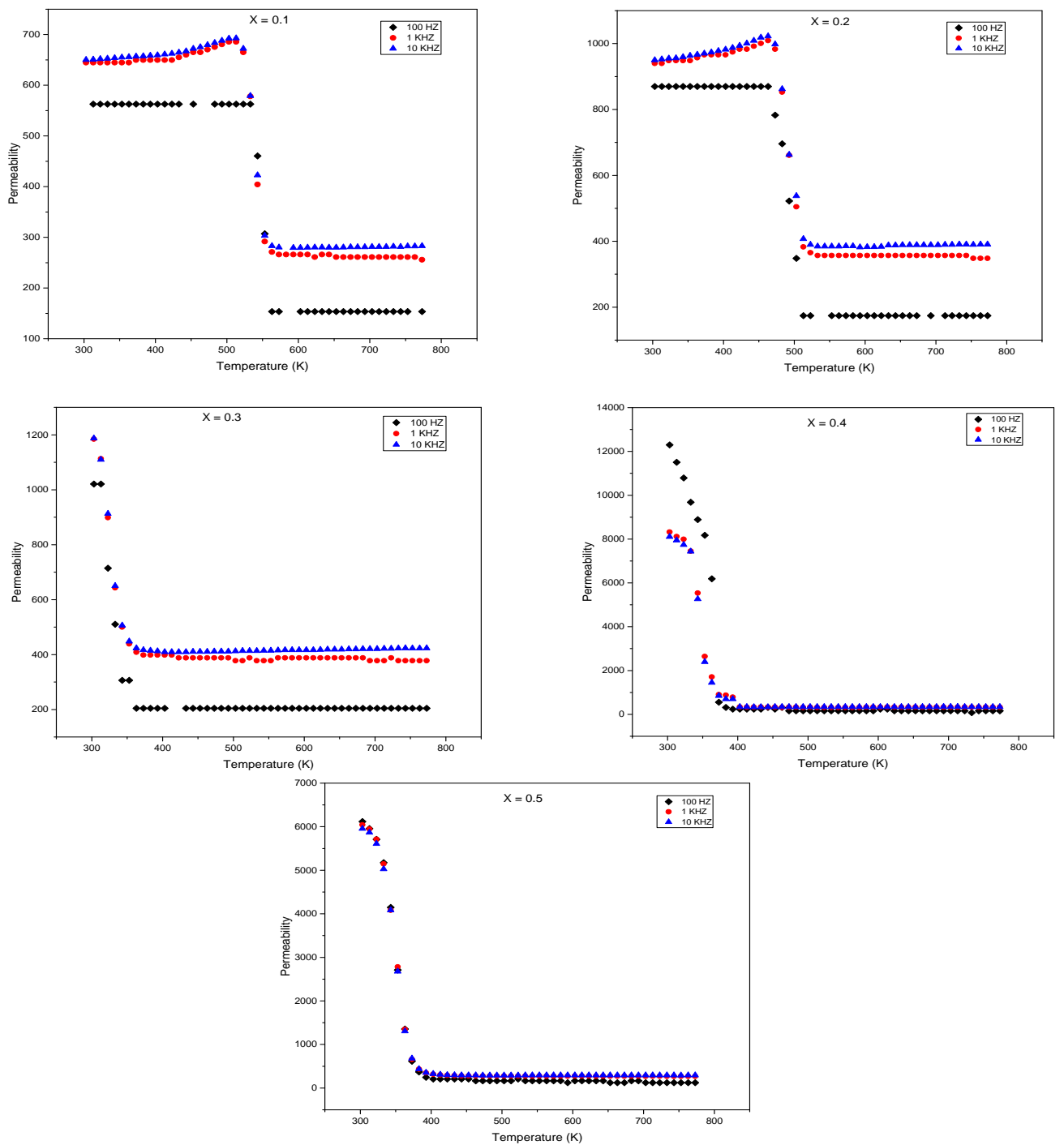

Figure (4-a): The initial magnetic permeability as a function of temperature for $\mathrm{Mg}_{1-\mathrm{x}} \mathrm{Zn}_{\mathrm{x}} \mathrm{Fe}_{2} \mathrm{O}_{4}$ prepared by standard ceramic technique at different frequencies $(100 \mathrm{~Hz}, 1 \mathrm{KHz}$ and $10 \mathrm{KHZ})$ 

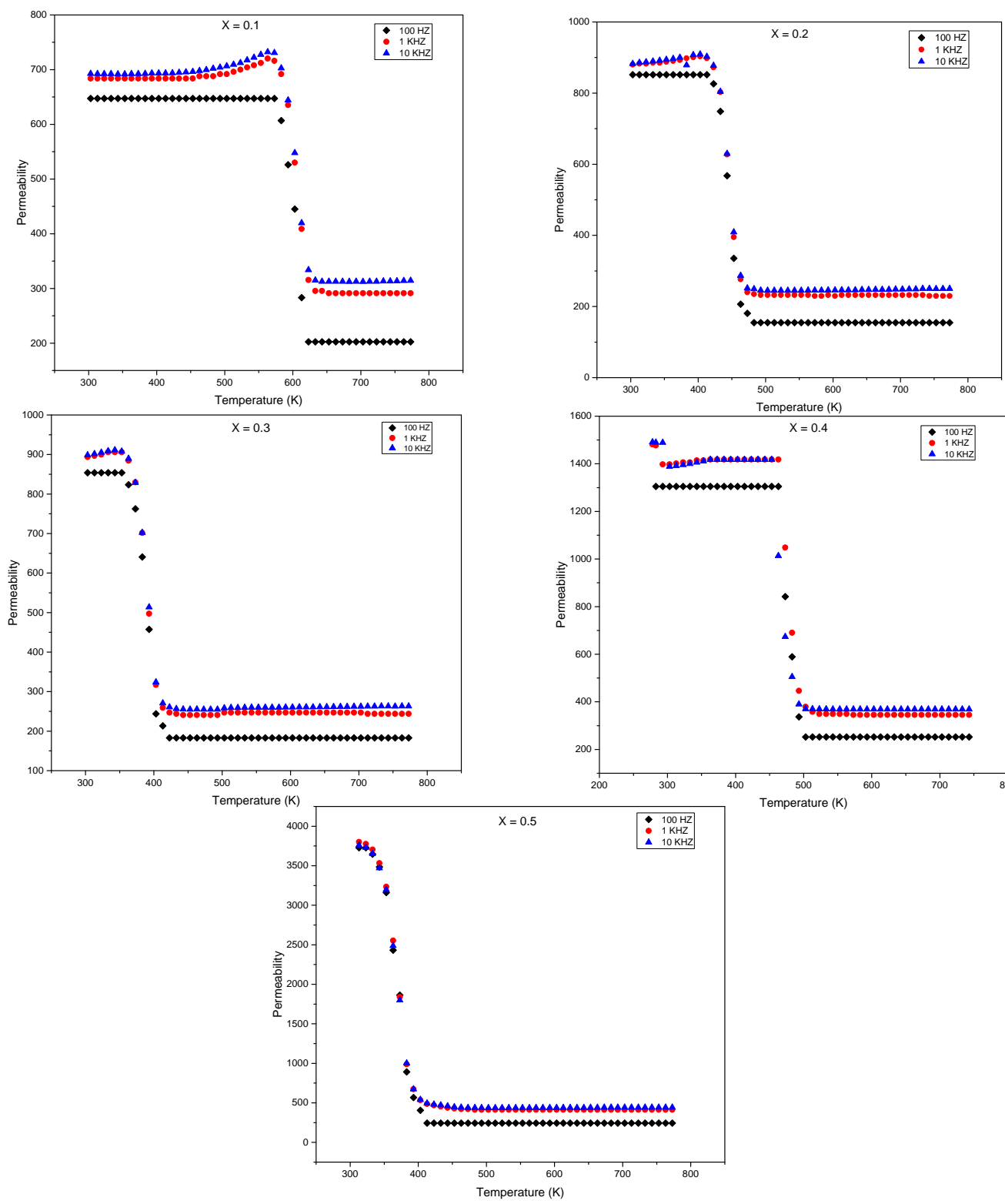

Figure (4-b): The initial magnetic permeability as a function of temperature for $\mathrm{Mg}_{1-\mathrm{x}} \mathrm{Zn}_{\mathrm{x}} \mathrm{Fe}_{2} \mathrm{O}_{4}$ prepared by mechanical ball milling method at different frequencies $(100 \mathrm{~Hz}, 1 \mathrm{KHz}$ and $10 \mathrm{KHZ})$

Table (3): The value of $\left(T_{c}\right)$ Curie temperature form DC and magnetic measurements, and the rate of change of $\left(\mu_{i}\right)$

\begin{tabular}{ccccccc}
\hline X content & Tc K & $\begin{array}{c}\text { Tc K } \\
\text { permeability }\end{array}$ & Slope & $\begin{array}{c}\text { Tc K } \\
\text { DC }\end{array}$ & $\begin{array}{c}\text { Tc K } \\
\text { permeability }\end{array}$ & Slope \\
\hline & DC & \multicolumn{2}{c}{ ceramic } & \multicolumn{3}{c}{ Ball milling } \\
$\mathbf{X}=\mathbf{0 . 1}$ & 578 & 560 & 5.851 & 584 & 630 & 8.376 \\
$\mathbf{X}=\mathbf{0 . 2}$ & 480 & 510 & 15.059 & 569 & 475 & 12.605 \\
$\mathbf{X}=\mathbf{0 . 3}$ & 475 & 350 & 16.479 & 563 & 410 & 13.704 \\
$\mathbf{X}=\mathbf{0 . 4}$ & 469 & 375 & 138.955 & 549 & 500 & 25.641 \\
$\mathbf{X}=\mathbf{0 . 5}$ & 454 & 380 & 89.573 & 478 & 400 & 54.733 \\
\hline
\end{tabular}

Scanning electron microscopy (SEM) 
Figures. (5 a, b) show the (SEM) micrographs of all $\mathrm{Mg}_{1-\mathrm{x}} \mathrm{Zn}_{\mathrm{x}} \mathrm{Fe}_{2} \mathrm{O}_{4}$ samples prepared by ball milling and the samples prepared by usual ceramic method. It was shown that the sample $(\mathrm{x}=0.4)$ has a high grain size for ball milling sample whereas sample $(\mathrm{x}=0.3)$ the highest value for ceramic samples.

The results reflect the dissolution of $\mathrm{Zn}$ in the $\mathrm{Mg}$ ferrite lattice becomes maximum at $(\mathrm{x}=0.4)$ and $(\mathrm{x}=0.3)$ for ball milling and ceramic samples respectively.

According to the relation of Globus model [10, 11] there is a direct proportionality between permeability and grain size. Our previous results of magnetic permeability show that the sample at $(\mathrm{x}=0.4)$ has highest value of magnetic permeability indicating the presence of correlation between the microstructure and magnetic properties.
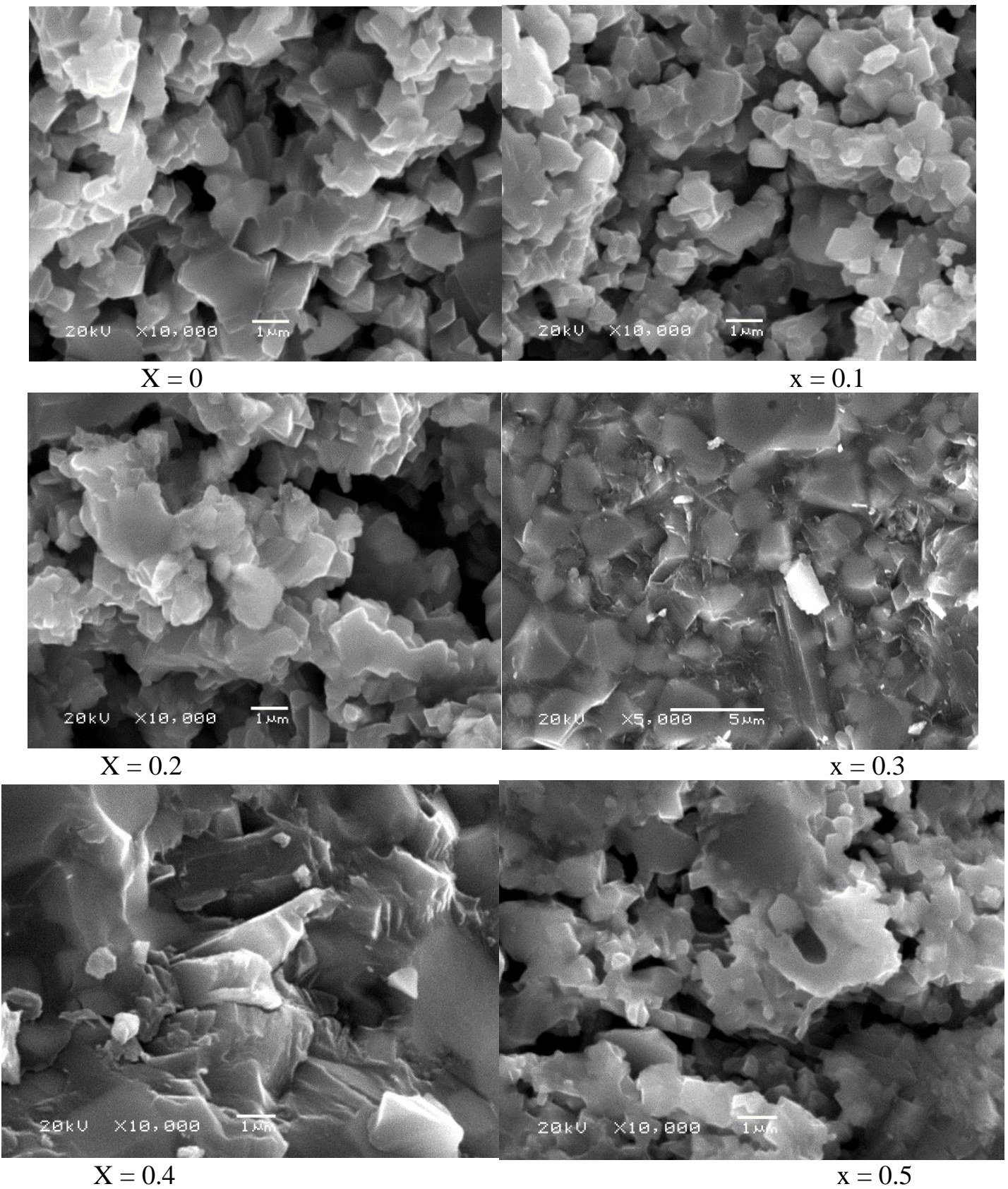

Figure (5-a): SEM micrographs for $\mathrm{Mg}_{1-\mathrm{x}} \mathrm{Zn}_{\mathrm{x}} \mathrm{Fe}_{2} \mathrm{O}_{4}$ prepared by standard ceramic technique 

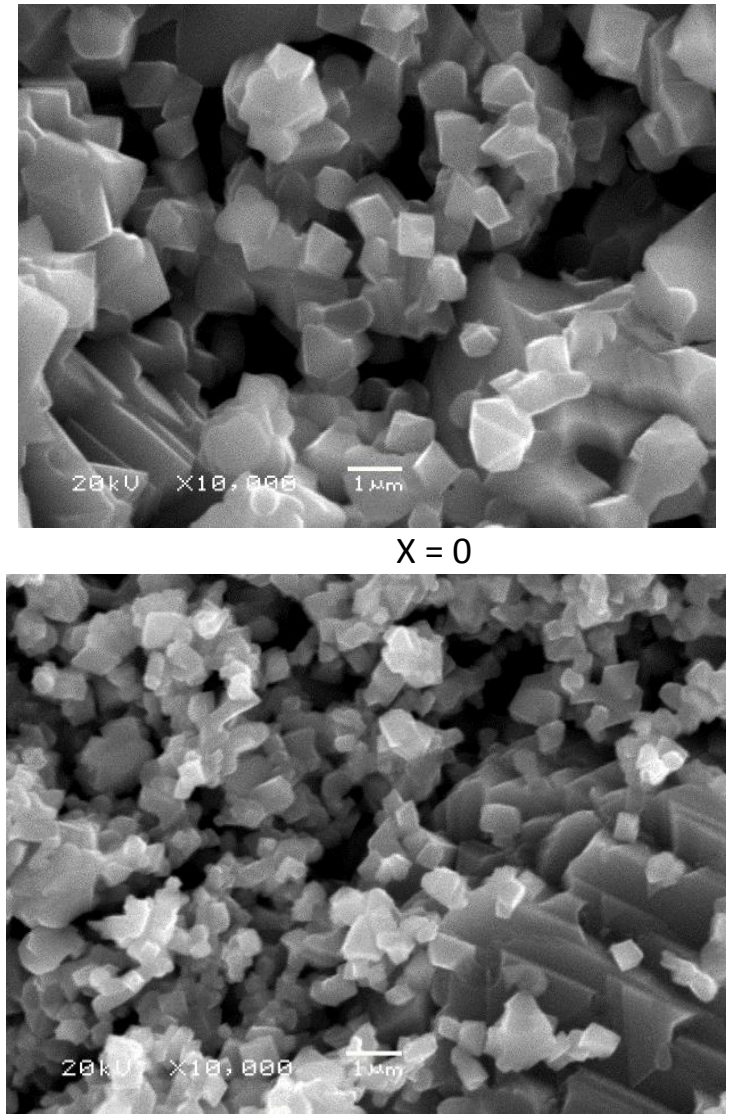

$X=0.2$

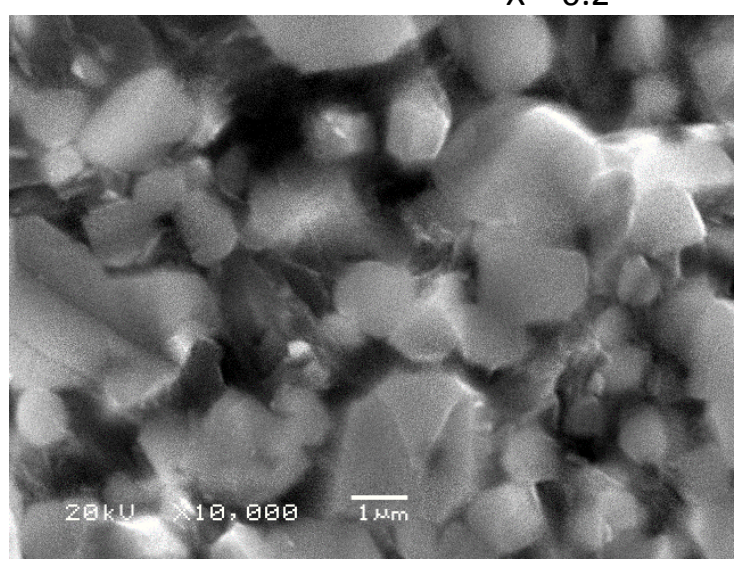

$X=0.4$

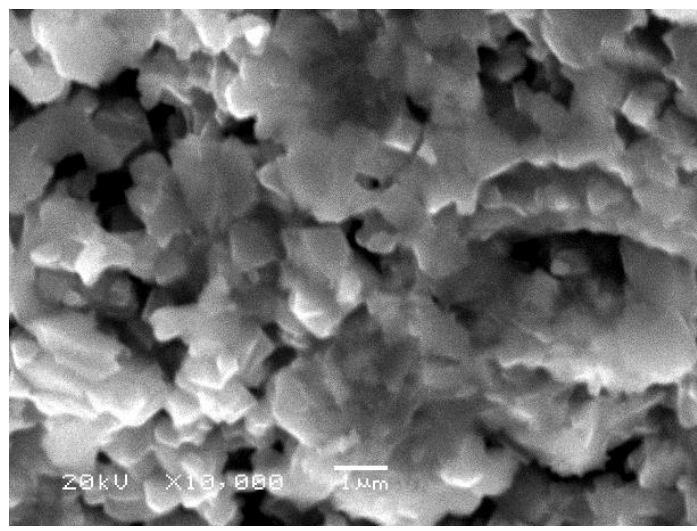

$\mathrm{x}=0.1$

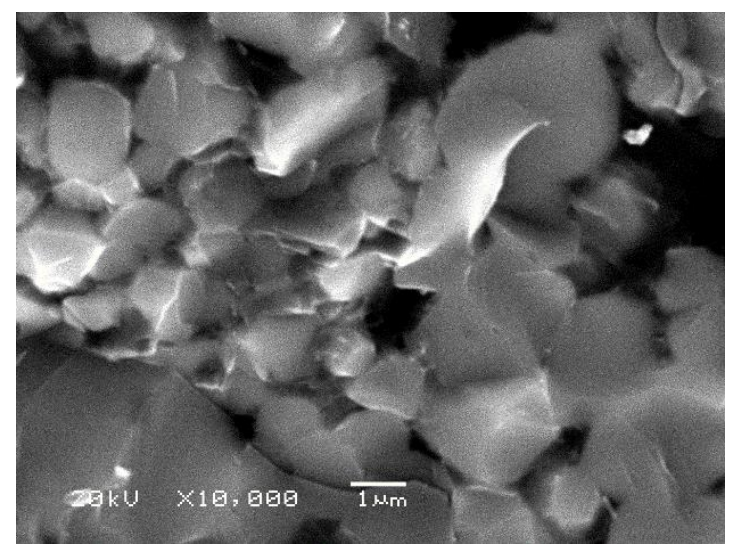

$\mathrm{x}=0.3$

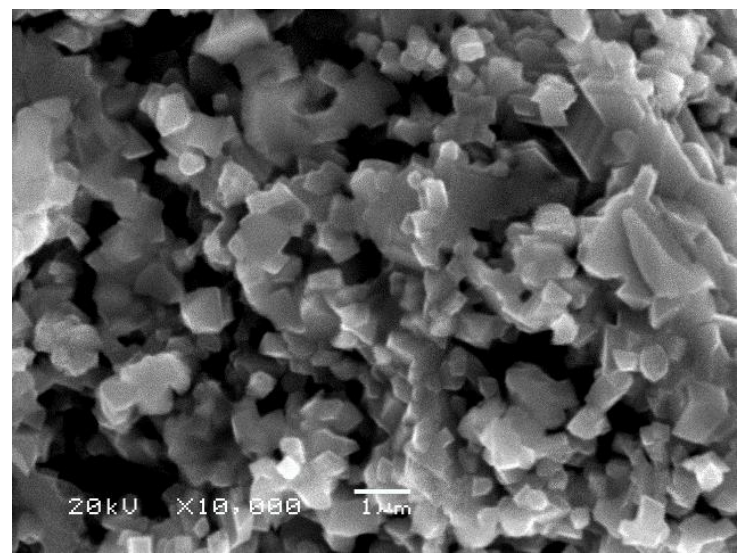

$x=0.5$

Figure (5-b): SEM micrographs for $\mathrm{Mg}_{1-\mathrm{x}} \mathrm{Zn}_{\mathrm{x}} \mathrm{Fe}_{2} \mathrm{O}_{4}$ prepared by mechanical ball milling method

\section{Conclusion}

Nano-ferrite $\mathrm{Mg}_{1-\mathrm{x}} \mathrm{Zn}_{\mathrm{x}} \mathrm{Fe}_{2} \mathrm{O}_{4}$ samples have been prepared by both ball milling and usual ceramic methods. The crystallite size of the studied samples was calculated from XRD examinations, and was found to be in the nano-range between 35 to $65 \mathrm{~nm}$. It was found that the lattice parameters increase with increasing the zinc content $(x)$. This increase may be attributed to the fact that the $\mathrm{Zn}^{2+}$ ionic radius is larger than the $\mathrm{Mg}^{2+}$ ionic radius. IR investigation shows that the intensities of the absorption band $\left(v_{1}\right)$ and $\left(v_{2}\right)$ increase with increasing the $\mathrm{Zn}$ content, indicating the enhancement of the crystallinity of the samples. Increasing the $\mathrm{Zn}$ content leads to a decrease in the $\mathrm{T}_{\mathrm{c}}$ curie temperature for both systems by increasing $\mathrm{Zn}$ ions which is attributed the decrease of A-B exchange interaction. The SEM images clearly

Arab J. Nucl. Sci. \& Applic. Vol. 53, No. 1 (2020) 
show that the grain size is increases with increasing the $\mathrm{Zn}$ content.

\section{References}

1- P. Y. Reyes-Rodríguez, et al., J. Magn. Magn. Mater. 427, (2017) $268-271$.

2- C. Choodamani, G.P. Nagabhushana, B. Rudraswamy, G.T. Chandrapp. J. Materials Letters. 116, (2014) $227-230$.

3- D. Ravinder, K. Latha. J. Materials Letters. 41, (1999) $247-253$.

4- A.M. Shaikh, C.M. Kanamadi, B.K. Chougule. J. Materials Chemistry and Physics. 93, (2005) 548 551.

5- K.A. Mohammed, et al. Physica B. 407, (2012) 795804.

6- Z. Pedzich, et al. J. of the European Ceramic Society. 24, (2004) 1053 -1056.

7- E. Petrova, D. Kotsikau, V. Pankov, A. Fahmi. J. Magn. Magn. Mater. 473, (2019) 85-91.

8- S. Hajarpour, Kh. Gheisari, A. Honarbakhsh Raouf. J. Magn. Magn. Mater. 329, (2013) 165 -169.

9- Rohit Sharma, Prashant Thakur, Manoj Kumar, Pankaj Sharma, Vineet Sharma. J. Alloys and Compounds. 746, (2018) 532 -539.

10- C. Choodamani, B. Rudraswamy, G.T. Chandrappa. Ceramics International. 42, (2016) $10565-10571$.
11- S. Bid, S.K. Pradhan. J. Materials Chemistry and Physics. 82, (2003) 27 -37.

12- M. Sinha, H. Dutta, S.K. Pradhan. Physica E. 33, (2006) $367-369$.

13- $\quad$ M. W. Mukhtar, et al. J. Magn. Magn. Mater. 381, (2015) $173-178$.

14- $\quad$ S.T. Alone, Sagar E. Shirsath, R.H. Kadam, K.M. Jadhav, J. Alloys Compds. 509 (2011) 50555060.

15- $\quad$ B.D. Cullity, Elements of X-ray Diffraction (Addison-Wesley, Reading, MA, 1959) p. 514.

16- P. Yajaira, et al. J. Magn. Magn. Mater. 427, (2017) $268-271$.

17- O.M. Hemeda, M.I. Abdel-Ati, B.I. Salem, A.M.A. Henaish, F.S. El-Sbakhy Eur. Phys. J. Plus. 133, (2018) $531-540$.

18- A. Sattar, H. El-Sayed, W. Agami, A. Ghani. Am J Appl Sci 2007, 4(2):89-93.

19- S. A. Patil, B. V. Bhise, A. K. Ghatage. Mater. Chem.and Phys. Society Japan, 41 (1976) 1216 1223.

20- H. Dutta, M. Sinha, Y.C. Lee, S.K. Pradhan. Materials Chemistry and Physics. 105 (2007) 31 37.

21- S.F. Mansour, M.A. Abdo, S.I. El-Dek. Patil. J. Magn. Magn. Mater. 422 (2017) $105-111$.

22- $\quad$ M. A. Rafiq, et al. Ceramics International. 41 (2015) $10501-10505$.

23- Y. Yamamoto, H. Tanaka, T. Kawai. J. Magn. Magn. Mater. 8 (2003) 261- 263. 